Lishchynska-Martyniuk O. Tactics of Presenting a Person for Identification Taking into Account the Mental State of the Juvenile Victims of Violent Crimes. The article highlights the issue of the mental state peculiarities of minors who are victims of violent crimes, the features of the juvenile psyche in different age periods, and their most common reactions to psychological trauma. When presenting a person for identification, particular attention is paid to the mental health of the minors - victims of violent crimes. The author argues that the mental state of juvenile victims of violent crimes is manifested in the peculiarity of their mental processes, is the basis of the formation of testimonies, and causes some misrepresentation of the primary information about the crime. It should be taken into account by the investigator in choosing the tactics of presenting a person for identification to a minor victim. The duration, degree and nature of the influence of the mental state on the minor victim, the degree of his awareness of it, the adequacy of the situation, the dominance of one or another situational component influence the choice of the investigator's tactics in investigative actions involving assistance of the victim, and the assessment of his/her testimony obtained at presentation for identification. The tense and emotional state of the juvenile victim significantly inhibits the process of reproducing his testimony. Therefore, taking into account the reminiscence, which determines the greater productivity and content of delayed reproduction of information, it is advisable to plan the presentation for identification of the juvenile victim later, but not later than three or four days after the crime, because then there may be a process of forgetting.

Key words: juvenile victims, mental state, violent crimes, presenting a person for identification.

УДК 342.739

DOI https://doi.org/10.32782/2409-4544/2019-2/24

I. Озімок

\title{
Конституційно-правове регулювання права власності на землю в Україні
}

Земля як об'єкт права власності регулюється в першу чергу цивільним, екологічним i земельним законодавством. Разом 3 тим, конституційно-правове регулювання права власності на землю має визначальний характер для всіх галузей права. Конституція України досить змістовно регулює право власності на землю, визнаючи землю природним ресурсом і об'єктом права власності. Крім того, конституційними нормами регулюються окремі питання форм власності, принципи реалізації права власності, захист і гарантованість права власності на землю, містяться вказівки на суб'єктів права власності на землю, а також обов'язок не використовувати власність на шкоду людині і суспільству. Така правова регламентація конституційного права власності на землю в порівнянні 3 конституціями багатьох країн світу є більш детальної, що безпосередньо пов'язано з важливістю землі для вітчизняної економіки і національної безпеки. Подібне правове регулювання частково спостерігається в конституціях низки пострадянських країн, в яких землях відводиться особливе місце в конституційно-правовому регулюванні. Ст. 14 Конституції України розвиває принципові положення, закріплені в ст. 13 Основного Закону. Вона визначає структуру земельного законодавства та закріплює основні засади регулювання земельних відносин у сучасних умовах і на перспективу. У ній також визначається правовий режим одного з найважливіших природних ресурсів - землі, яка визнана основним національним багатством, що перебуває під особливою охороною держави. Питання щодо права власності на землю мають регламентуватись виключно законами як актами вищої юридичної сили, прийнятими Верховною Радою України відповідно до встановленої процедури.

Ключові слова: Конституція України, право власності, право власності на землю

Постановка наукової проблеми та її значення. Розглядаючи землю як об'єкт правового регулювання, теоретики і практики виходять в першу чергу з розуміння землі як об'єкта права власності. В умовах триваючої земельної реформи інтерес до пошуку оптимальних шляхів врегулювання права власності на землю не вщухає. Земля, як об'єкт права власності, регулюється в першу чергу цивільним, екологічним та земельним законодавством. Разом з тим, конституційно-

(ㄷ) Озімок I., 2019 
правове регулювання права власності на землю має визначальний характер для усіх інших галузей права, хоча і не було предметом грунтовного дослідження.

Аналіз досліджень цієї проблеми. Проблемам права власності на землю приділяли увагу фахівці різних галузей права, зокрема, цивільного, земельного, екологічного, адміністративного, кримінального та ін. Питанню права власності на землю присвячені дослідження таких науковців, як С. Губарєв, I. Каракаш, I. Костяшкін, К. Кучерук, О. Харченко, М. Шульга та ін.. В рамках конституційно-правових досліджень праву власності на землю частково увага приділялась Ю. Фроловим, Л. Івершенко та ін.

Мета й завдання статті. Дослідження конституційно-правового регулювання права власності на землю не було предметом самостійних наукових розвідок. Наведене вище зумовлює мету статті - крізь призму узагальненого аналізу наукової літератури дослідити конституційноправові норми, що регулюють право власності на землю.

Виклад основного матеріалу й обгрунтування отриманих результатів дослідження. Конституція України встановила окремі основоположні засади права власності на землю в ряді статей. Найперше варто розпочати 3 ч. 1 ст. 13 Конституції України, в якій зазначено, що земля, іiі надра, атмосферне повітря, водні та інші природні ресурси, які знаходяться в межах території України, природні ресурси ії континентального шельфу, виключної (морської) економічної зони $\epsilon$ об'єктами права власності Українського народу. Від імені Українського народу права власника здійснюють органи державної влади та органи місцевого самоврядування в межах, визначених цією Конституцією.

Конституція проголошує право власності на природні ресурси Українського народу, який має право володіння, користування і розпоряджання природними багатствами країни. Як природний ресурс виступає будь-яка частина навколишнього середовища, яку людина використовує чи може використовувати для задоволення своїх потреб з певною метою. До їх складу належать об'єкти природи, відносно стабільні, і ті, які постійно змінюються, підлягають або не підлягають індивідуалізації, мають здатність відтворюватися та відновлюватися чи такої здатності не мають. Розрізняють також природні ресурси, які за своїми фізичними властивостями можуть бути об' єктами права власності, і ресурси, які такими об'єктами виступати не можуть. До перших належить земля, іiі надра, води, ліси, дикий рослинний і тваринний світ тощо. До других - клімат певного регіону, сонячна радіація, енергія виміру, атмосферне повітря тощо. Природні ресурси створюють матеріальну основу розвитку суспільства. Оскільки всі вони забезпечують життєдіяльність людей, то переважна більшість з них характеризуються приналежністю [1, с. 46-47].

У ст. 13 Основного Закону держави визначається конституційно-правовий режим землі, іiі надр, атмосферного повітря, водних ресурсів, рослинного та тваринного світу, природно-заповідного фонду та інших природних ресурсів у межах території України, а також природних ресурсів іiі континентального шельфу та виключної (морської) економічно зони, закріплюється соціальна функція власності щодо їх використання на юридичному титулі права власності, встановлюються гарантії захисту державою усіх суб'єктів права власності і господарської діяльності, які є рівними перед законом. Від імені Українського народу права власника на землю здійснюють виключно органи державної влади та місцевого самоврядування в межах повноважень, визначених Конституцією України, із збереженням сталості і незмінності права власності на землю Українського народу в межах території України та неможливістю без конституційних змін здійснення цього права іншими, не передбаченими Основним Законом суб’ єктами [2, с. 99].

Закладену в Основному Законі концепцію права власності на природні ресурси в цілому та землю зокрема розвивають інші статті Конституції України. Так, ст. 14 Конституції України передбачає, що земля $є$ основним національним багатством, що перебуває під особливою охороною держави. Право власності на землю гарантується. Це право набувається і реалізується громадянами, юридичними особами та державою виключно відповідно до закону. Конституція, зважаючи на виключно важливе значення землі у всіх сферах життєдіяльності України та її народу, відокремлює землю від інших об'єктів нерухомості і запроваджує принцип ії особливої охорони з боку держави. Ця охорона спрямована на збереження плодючості землі, підвищення іiі продуктивності, використання земельних ресурсів у відповідності з їх природним призначенням, недопущення забруднення землі шкідливими для здоров'я людини і тварин елементами тощо. Однак це не означає виключення землі із системи господарських відносин. Мова йде лише про законодавче запровадження деяких обмежень свободи ії використання. Конституція гарантує право власності на землю, яке може існувати і як право приватної власності, і як право державної та комунальної власності. Це право набувається відповідними суб'єктами виключно за законом. Конституційно 
можливі форми права власності на землю забезпечуються тими ж гарантіями, що і право власності на будь-які інші об'єкти [3, с. 53-54].

На конституційному рівні право власності загалом регламентується частинами 3 i 4 ст. 13 Конституції України, де зазначено, що власність зобов'язує, власність не повинна використовуватися на шкоду людині і суспільству, а держава забезпечує захист прав усіх суб'єктів права власності і господарювання, соціальну спрямованість економіки. Усі суб'єкти права власності рівні перед законом.

Власність не тільки дає переваги тим, хто іiі має, а й покладає певні обов’язки. Це конституційне положення пов' язане з принципом поєднання інтересів власника, суспільства та інших власників i користувачів природними ресурсами. Захист інтересів власності не повинен перешкоджати ефективній природоохоронній діяльності [3, с. 52].

Ст. 14 Конституції України розвиває принципові положення, закріплені в ст. 13 Основного Закону. Вона визначає структуру земельного законодавства та закріплює основні засади регулювання земельних відносин у сучасних умовах і на перспективу. У ній також визначається правовий режим одного 3 найважливіших природних ресурсів - землі, яка визнана основним національним багатством, що перебуває під особливою охороною держави. Ці положення створюють принципово нову в Україні конституційну основу як для галузевого (земельного та цивільного) законодавства, так і для господарської діяльності [1, с. 72].

Конституція України проголосила землю основним національним багатством. Останнє у широкому розумінні являє собою все те, чим так чи інакше володіє певна нація. Тобто до національного багатства включаються не лише матеріальні блага, а й усі природні ресурси, клімат, витвори мистецтва та ін. [2, с. 105]. Національне багатство - один 3 головних показників економічного стану держави. Воно визначається як сукупність створених і накопичених у країні працею всього суспільства благ, рівня освіти, виробничого досвіду, майстерності, творчого обдаровання населення тощо. До його складу входять суспільне, тобто створено працею людей, речове багатство; природні багатства (природні ресурси); нематеріальне багатство (освітній, кваліфікаційний, науковий, культурний потенціал та ін.). У свою чергу природні багатства включають засоби до існування та засоби праці [1, с. 73].

Ст. 14 Конституції України закріпила, що таке основне національне багатство, як земля, перебуває під особливою охороною держави. Це означає, що серед інших речей матеріального світу, серед інших об' єктів правовідносин пріоритет належить саме землі, а правовий режим інших об' єктів (зокрема, нерухомості), безпосередньо залежить від землі, пов'язаний із правовим режимом останньої [2, с. 105]. Згідно із ст. 14 Конституції України право власності на землю набувається і реалізується громадянами, юридичними особами та державою виключно відповідно до закону. Порядок набуття, реалізації та припинення права власності на землю визначено кодифікованим актом земельного законодавства - Земельним кодексом України від 25.10.2001 p. [2, с. 107].

Оскільки йдеться саме про право власності на землю, не можна оминути увагою ст. 41 Конституції України, яка передбачає, що кожен має право володіти, користуватися і розпоряджатися своєю власністю, результатами своєї інтелектуальної, творчої діяльності. Право приватної власності набувається в порядку, визначеному законом. Громадяни для задоволення своїх потреб можуть користуватися об'єктами права державної та комунальної власності відповідно до закону. Ніхто не може бути протиправно позбавлений права власності. Право приватної власності $є$ непорушним. Примусове відчуження об'єктів права приватної власності може бути застосоване лише як виняток 3 мотивів суспільної необхідності, на підставі і в порядку, встановлених законом, та за умови попереднього і повного відшкодування їх вартості. Примусове відчуження таких об'єктів 3 наступним повним відшкодуванням їх вартості допускається лише в умовах воєнного чи надзвичайного стану. Конфіскація майна може бути застосована виключно за рішенням суду у випадках, обсязі та порядку, встановлених законом. Використання власності не може завдавати шкоди правам, свободам та гідності громадян, інтересам суспільства, погіршувати екологічну ситуацію і природні якості землі.

Земля є важливим економічним ресурсом, джерелом національного багатства, від порядку іiі використання залежить економічне зростання, рівень життя i здоров'я нації. Земля виступає особливим об'єктом права власності, обіг якого регулюється нормами цивільного права та земельного права, а основні засади такого регулювання закладено в нормах Конституції.

Крім того, в пп. 5 і 7 ч 1 ст. 92 Конституції України зазначається, що виключно законами України визначаються засади використання природних ресурсів, виключної (морської) економічної зони, континентального шельфу, освоєння космічного простору, організації та експлуатації енергосистем, транспорту і зв'язку, а також правовий режим власності. Тож питання набуття, 
припинення, реалізації, гарантування, охорони права власності на землю, як особливий природний ресурс, має визначатись виключно законами України. Тим самим Конституцією закріплений примат повноважень Верховної Ради України як законодавчого органу в правовому регулюванні земельних відносин насамперед відносин земельної власності $[1$, с. 76]. У цій статті реально відбився принцип пріоритету (верховенства) закону в системі інших нормативно-правових актів, за допомогою якого здійснюється правове регулювання найважливіших суспільних відносин [1, с. 440].

Оскільки закони мають вищу юридичну силу в системі нормативно-правових актів, то цілком зрозуміло, що саме ними повинні регулюватися найважливіші питання суспільних відносин. Саме про це і свідчить дана стаття Конституції України [3, с. 207]. Отож, питання щодо права власності на землю мають регламентуватись виключно законами як актами вищої юридичної сили, прийнятими Верховною Радою України відповідно до встановленої процедури.

Кабінет Міністрів України наділений компетенцією щодо розпорядження державними землями. Відповідно до п. 5 ст. 116 Конституції України він забезпечує рівні умови розвитку всіх форм власності; здійснює управління об'єктами державної власності відповідно до закону. У змісті п. 5 ст. 116 Конституції України об'єднано два окремих положення, достатньо автономних за своїм змістом і природою. Перше - «забезпечує рівні умови розвитку всіх форм власності», що частково грунтується на положенні ст. 13 Конституції України, відповідно до якого «держава забезпечує захист усіх суб' єктів права власності і господарювання», друге - «здійснює управління об' єктами державної власності відповідно до закону», що утворює окрему, надзвичайно важливу функцію Уряду. Таким чином, щонайменше останнє положення п. 5 ст. 116 Конституції України має зайняти окреме місце в закріпленні системи функцій Уряду. Забезпечення ж рівних умов розвитку всіх форм власності скоріше є принципом діяльності, аніж його функціональним завданням. Слід звернути увагу також і на проблемну визначеність щодо розвитку саме форм власності. Коректніше було б вказати на розвиток суб’ єктів господарювання різних форм власності. Слід також визнати, що назване положення має більше ідеологічне навантаження, ніж юридичне. Разом 3 тим практична діяльність держави у сфері економічного розвитку передбачає запровадження спеціальних режимів господарювання, що фактично можуть створювати окремі переваги, наприклад, суб'єктам приватного малого бізнесу, в аграрній сфері, у сфері оборонно-промислового комплексу, представленого переважно державними підприємствами тощо. Саме тому важливо забезпечити не математичну рівність умов розвитку суб'єктів господарювання різних форм власності, а максимально можливі для кожного з них умови розвитку як такого [2, с. 806-807].

Ще однією нормою, що безпосередньо регламентує конституційне право власності на землю $є$ частина 1 ст. 142 Конституції України. Відповідно до іiі положень матеріальною і фінансовою основою місцевого самоврядування є рухоме і нерухоме майно, доходи місцевих бюджетів, інші кошти, земля, природні ресурси, що є у власності територіальних громад сіл, селищ, міст, районів у містах, а також об'єкти їхньої спільної власності, що перебувають в управлінні районних і обласних рад.

Стаття 142 Конституції України визначає принципові засади формування і структуру матеріальної і фінансової основи місцевого самоврядування в Україні. Це зумовлено передусім тим, що ефективне функціонування системи місцевого самоврядування значною мірою залежить не стільки від обсягу повноважень, якими наділені територіальні громади та утворювані ними органи, скільки від наявності в їх володінні та вільному розпорядженні матеріальних, фінансових та інших ресурсів, необхідних для виконання покладених на них завдань [3, с. 315].

Отже, як матеріальну основу місцевого самоврядування Конституція України називає перш за все рухоме і нерухоме майни, до складу якого можуть входити будівлі, споруди, приміщення та їх комплекси житлового, виробничого, адміністративного характеру, об'єкти інженерної інфраструктури, благоустрою, обладнання, об’єкти соціально-культурного, побутового, інформаційно-видавничого призначення, транспортні засоби, шляхи, мости шляхопроводи, предмети, що є пам'ятками історії і культури місцевого значення, тощо [1, с. 710].

До матеріальної основи місцевого самоврядування Конституція відносить також землю і природні ресурси, що перебуваю у власності територіальних громад [1, с. 710]. Як зазначено ч. 1 і 2 ст. 83 Земельного кодексу України від 25.10.2001, землі, які належать на праві власності територіальним громадам сіл, селищ, міст, є комунальною власністю. У комунальній власності перебувають: а) усі землі в межах населених пунктів, крім земельних ділянок приватної та державної власності; б) земельні ділянки, на яких розташовані будівлі, споруди, інші об'єкти нерухомого майна комунальної власності незалежно від місця їх розташування [4]. 
Висновки. Конституція України досить змістовно регулює право власності на землю, визнаючи землю природним ресурсом та об’єктом права власності. Крім того, конституційними нормами регулюються окремі питання форм власності, засади реалізації права власності, захист та гарантованість права власності на землю, містяться вказівки на суб'єктів права власності на землю, а також обов'язок не використовувати власність на шкоду людині і суспільству. Така правова регламентація конституційного права власності на землю $\epsilon$ досить розлогою, порівняно 3 конституціями багатьох країн світу, що безпосередньо пов'язано зі значимістю землі для вітчизняної економіки та національної безпеки. Подібне правове регулювання частково спостерігається в конституціях ряду пострадянських країн, де землі відводиться особливе місце в конституційноправовому регулюванні. Разом 3 тим, конституційне право власності на землю в Україні розглядається як право Українського народу, що підкреслює цінність та важливість зазначеного права, в порівнянні з регламентацією прав, належних людині чи громадянину.

\section{Джерела та література}

1. Конституція України: науково-практичний коментар / [В. Б. Авер'янов, О. В. Батанов, Ю. В. Баулін та ін.]; [Ред. кол.: В. Я. Тацій, Ю. П. Битяк, Ю. М Грошевой та ін.]. - Харків: Видавництво «Право»; К.: Концерн «Видавничий Дім «Ін Юре», 2003. - 808 с.

2. Конституція України. Науково-практичний коментар / редкол.: В. Я. Тацій (голова редкол.), О. В. Петришин (відп. секретар), Ю. Г. Барабаш та ін.; Нац. акад. прав. наук України. - 2-ге вид., переробл. і допов. - Х. : Право, 2011. - 1128 с.

3. Коментар до Конституції України / [В. Б. Авер'янов, В. Ф. Бойко, В. І. Борденюк та ін.]; Ін-т законодавства Верхов. Ради України ; [редкол.: В. Ф. Опришко (голова) та ін.]. - К., 1996. - 376 с.

4. Земельний кодекс України від 25 жовтня 2001 р. 3 наступними змінами і доповненнями № 2768-III [Електронний ресурс]. - Режим доступу : https://zakon.rada.gov.ua/laws/show/2768-14.

Озимок И. Конституционно-правовое регулирование права собственности на землю в Украине. Земля, как объект права собственности, регулируется в первую очередь гражданским, экологическим и земельным законодательством. Вместе с тем, конституционно-правовое регулирование права собственности на землю имеет определяющий характер для всех отраслей права. Конституция Украины достаточно содержательно регулирует право собственности на землю, признавая землю природным ресурсом и объектом права собственности. Кроме того, конституционными нормами регулируются отдельные вопросы форм собственности, принципы реализации права собственности, защита и гарантированность права собственности на землю, содержатся указания на субъектов права собственности на землю, а также обязанность не использовать собственность во вред человеку и обществу. Такая правовая регламентация конституционного права собственности на землю по сравнению с конституциями многих стран мира является более детальной, что напрямую связано с важностью земли для отечественной экономики и национальной безопасности. Подобное правовое регулирование частично наблюдается в конституциях ряда постсоветских стран, в которых землям отводится особое место в конституционно-правовом регулировании. Ст. 14 Конституции Украины развивает принципиальные положения, закрепленные в ст. 13 Основного Закона. Она определяет структуру земельного законодательства и закрепляет основные принципы регулирования земельных отношений в современных условиях и на перспективу. В ней также определяется правовой режим одного из важнейших природных ресурсов - земли, которая признана основным национальным богатством, находящимся под особой охраной государства. Вопрос о праве собственности на землю должен регламентироваться исключительно законами как актами высшей юридической силы, принятыми Верховной Радой Украины в соответствии с установленной процедурой.

Ключевые слова: Конституция Украины, право собственности, право собственности на землю.

Ozymok I. Constitutional and Legal Regulations of Land Ownership Rights in Ukraine. Land as an issue of property rights, is governed primarily by civil, environmental, and land laws. At the same time, the constitutional and legal regulation of land ownership is decisive for all branches of law. The Constitution of Ukraine substantially regulates land ownership by recognizing land as a natural resource and an object of property rights. In addition, the constitutional norms regulate nearly all issues of ownership, the principles of the implementation of property rights, protection and guarantee of land ownership, instructions on subjects 
of land ownership, as well as an obligation not to use the property to the detriment of a human and society. Such legal regulation of the constitutional right of land ownership in comparison with the constitutions of many countries of the world is more detailed, which is directly related to the importance of land for the national economy and national security. The similar legal regulation is partially observed in the constitutions of most post-Soviet states, where land occupies a prominent place in the constitutional regulation. Art. 14 of the Constitution of Ukraine develops the basic provisions enshrined in Art. 13 of the Main Law. It determines the structure of land legislation and establishes the basic principles of regulation of land relations in modern conditions and in the future. It also defines the legal regime of one of the most important natural resources - land, which is recognized as the main national wealth, which is under special protection of the state. Issues of land ownership should be regulated exclusively by laws as acts of higher legal force, adopted by the Verkhovna Rada of Ukraine in accordance with the established procedure.

Key words: Constitution of Ukraine, property right, land ownership.

УДК 343.43

DOI https://doi.org/10.32782/2409-4544/2019-2/25

Д. Фелонюк

\section{Адміністративно-правові механізми протидії торгівлі людьми в контексті захисту прав і свобод громадян України за кордоном}

Проаналізовано національний механізм взаємодії суб'єктів, які здійснюють заходи щодо захисту прав та свобод громадян України за кордоном. Розглядаються особливості застосування поняття «торгівля людьми» в праві. Досліджуються масштабність проблеми і напрямки їі вирішення 3 урахуванням європейського досвіду. Звертається увага на необхідність тісної координації дій вітчизняних і міжнародних організацій щодо попередження та захисту громадян України від торгівлі людьми, боротьбою зі злочинністю пов'язаної з цими протиправними діями. Зроблено висновок, що національний адміністративно-правовий механізм протидії торгівлі людьми передбачає систему заходів, спрямованих на виявлення злочину торгівлі людьми, встановлення осіб, причетних до його скоєння і притягнення їх до відповідальності. Ефективність даного механізму залежить в значній мірі від взаємодії і координації дій між національними та міжнародними інститутами, сферою яких $\epsilon$ торгівля людьми. Цьому буде сприяти інтеграція українського законодавства до європейського а також співробітництво як державних так і недержавних суб'єктів, які здійснюють заходи у сфері протидії торгівлі людьми. Потребують узгоджених міждержавних дій процедури екстрадиції жертв торгівлі людьми, так як більшість справ завершується здебільшого їхнім арештом та депортацією. Відчувається брак висококваліфікованих працівників у системі правоохоронних органів, міграційних служб та інших установ, до компетенції яких належить протидія торгівлі людьми і надання допомоги потерпілим від цього злочину. Більш результативною в цьому плані є співпраця міжнародних правозахисних організацій та засобів масової інформації.

Ключові слова: торгівля людьми, права, свободи, громадянин, Україна.

Постановка наукової проблеми та її значення. В Конституції України закріплено право на життя, свободу, вільне пересування, особисту недоторканність, свободу праці та іншу не заборонену законом діяльність. Також громадянам України гарантується можливість вибору місця перебування і проживання в тому числі і за кордоном. Щодня тисячі наших співвітчизників перетинають кордон $\mathrm{i}$ тим потрапляють в правове поле іноземної держави. Одними 3 причин еміграції є можливість лікування, отримання освіти, роботи.

В останній період досить інтенсивно відбувається трудова еміграція, яка зумовлена з одного боку непростою соціально-економічною ситуацією в країні, а з іншого боку лібералізацією візового режиму з СС. За результатами репрезентативного опитування населення, здійсненого на замовлення Міжнародної організації з міграції (МОМ) в 2015 р., частка тих, хто працює за кордоном неофіційно, становить близько $41 \%$ від усіх громадян України, які працюють за кордоном [1]. Більшість 3 них

() Фелонюк Д., 2019 